\title{
Pollen Morphology Variation of Undergrowth Plants in Bantarbolang Nature Reserve, Pemalang, Central Java
}

\author{
Anisatul Khabibah Zaen*, Sukarsa, Siti Samiyarsih
}

\author{
Fakultas Biologi, Universitas Jenderal Soedirman \\ Jalan dr. Suparno 63 Purwokerto 53122 \\ *Email : anisakzaen@gmail.com
}

Article History:

Received : 29/08/2019

Accepted : 19/10/2019

\begin{abstract}
Undergrowth is a ground cover plant that is generally in the form of herbs, grass, or low shrubs. Mostly undergrowth is flowering plants. The Flower is part of plant for generative reproduction that consists of several organs that consist of pedicellus, receptacullum, perianthium, pistillum and stamen that contain pollen. Pollen is part of the flower that functions as a generative reproduction agent because it contains male gamete. Pollen has a distinctive character in each plant so that it can be used as a tool for identifying plants. Sampling location was conducted in Bantarbolang Nature Reserve, a conservation area located in Kebon Gede Village, Bantarbolang District, Pemalang Regency. The objective of research is to know the morphological character of undergrowth pollen in the Bantarbolang Nature Reserve. The research used a survey method with explorative sampling techniques. The variables observed are the morphological character of pollen with the parameters consist of pollen unit, shape, aperture, diameter, and ornamentation. Sample preparation uses the acetolysis method and descriptive data analysis. Based on the results of the research found 6 species of undergrowth with different pollen morphological characters in the pollen shape (sub-speroidal and prolate), aperture (tricolpate, tricolporate and fenestrate) and ornamentation type (psilate, reticulate, perforate and echinate). The pollen units of all species have the same type, monad.

Keywords: Bantarbolang, morphological character, nature reserve, pollen, undergrowth
\end{abstract}

\section{INTRODUCTION}

Ground cover plants or commonly referred to as undergrowth are all plants that can not grow up to the tree level (Kunarso \& Azwar, 2013). The undergrowth is usually in the form of herbs, grass, shrubs or low shrubs. There is a type of undergrowth that is annual, biannual or perennial in a solitary, clumped, erect or climbing. Undergrowth plants are generally a member of the family Poaceae, Cyperaceae, Araceae, Asteraceae, and ferns (Aththorick, 2005). The existence of undergrowth serves to maintain the balance of the ecosystem. The undergrowth will hold water from falling directly to the ground and reduce surface flow so that it can inhibit erosion. The undergrowth grows naturally among the main trees and is usually found in gardens even in the forest (Maisyaroh, 2010).

Most of the undergrowth is flowering wild plants that are available in nature (Widhiono \& Sudiana, 2015). Flowers are a tool for sexual reproduction in plants. Flowers of each plant have a large variation in structure, arrangement, and size. The important part of the flower consists of flower stalks, flower base (receptacle), protective leaves (brachtea) and flower jewelry (perianthium), stamen and pistil. In the stamens, the parts of flower which is carrying male gamete cells called pollen (Ratnasari, 2007). The pistil is a part of the flower that contains female gamete cells, while pollen is a part of the flower that carries male gamete cells (Allard, 1992). Besides as a reproductive tool in flowers, the morphological character of pollen is also used as a tool for plant determination and taxonomic evidence (Kumaladita, 2014). Morphological characters of pollen consist of symmetry, size, shape, exine ornamentation, stratification and aperture (Mikaf, 2013).

Bantarbolang Nature Reserve is one of the conservation areas located in Kebon Gede Village, Bantarbolang District, Pemalang Regency. This nature reserve is located at an altitude of $\pm 100 \mathrm{~m}$ above sea level with flat typography conditions, soil type latosol brown redness, daily temperatures around $26^{\circ}-28^{\circ} \mathrm{C}$, minimum air humidity of $77 \%$ in September and a maximum of $85 \%$ in January, while rainfall averages $3000-4000 \mathrm{~mm} /$ year. This area is dominated by teak plants (Tectona grandis $\mathrm{L}$. f .) and other plants such as undergrowth plants (Central Java BKSDA, 2018).

Morphological variations of undergrowth pollen in the Bantarbolang Nature Reserve area are not well known because research and exploration in the area are still limited. Because of the limited morphological variation information about the pollen of lower plants, it is necessary to collect data on the morphological variation of undergrowth pollen in the Bantarbolang Nature Reserve area. The data collection is very important as an inventory activity, useful for knowing the diversity of a 
species in the habitat and can help the process of determination for further research (Suharti, 2015).

Based on the background above, the researcher has observed pollen morphology of undergrowth plants found in the Bantarbolang Nature Reserve. The data obtained are the morphological character of pollen consist of units, polar length, equatorial diameter, shape, aperture, and type of ornamentation of undergrowth species found.

Based on the explanation above, the problems is how are the morphological characters of the pollen found in the Bantarbolang Nature Reserve. The purpose of this research is to know the morphological character of undergrowth pollen found in the Bantarbolang Nature Reserve.

The benefit of this research is the morphological character of the undergrowth pollen in Bantarbolang Nature Reserve is available so that it will be useful for future research for identification in the event of an ecosystem change.

\section{MATERIALS AND METHOD}

Sampling locations conducted in the Bantarbolang Nature Reserve, Pemalang, Central Java (7¹'11.774”S, 109¹5'16.737’'E). The laboratory research and identification conducted at the Laboratory of Plant Structure and Development of the Faculty of Biology, Jenderal Sudirman University. This research was conducted in May 2019 - August 2019. This research used survey methods with explorative sampling techniques. The variable that observed are morphological characters of pollen. The parameter that observed are pollen unit, polar axis length, equatorial diameter, shape, aperture, and ornamentation type.

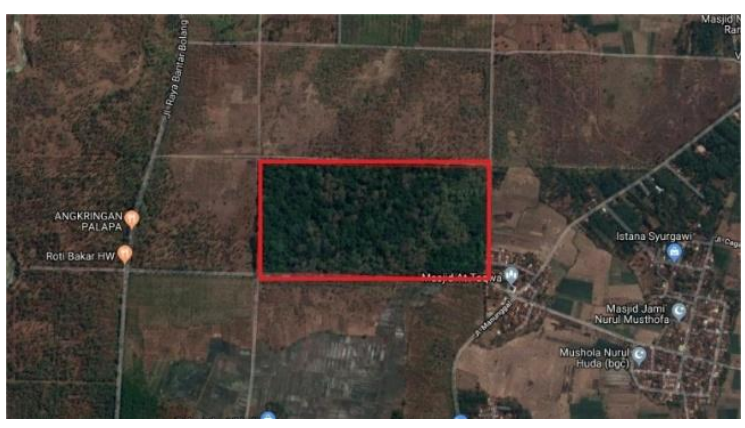

Figure 1. Map of research location in Bantarbolang Nature Reserve. Scale 1: 200 (BKSDA Jateng, 2018).

Pollen samples were taken from undergrowth flowers found in the Bantarbolang Nature Reserve by inserted them into vial bottle that contain glacial acetic acid, then fixed for 24 hours. Pollen samples are transferred to the centrifuge tube and sulfuric acid 1-2 dropped with a ratio 9: 1 of glacial acetic acid and sulfuric acid through the tube wall. The pollen sample in the centrifuge tube is heated over a waterbath at $60^{\circ} \mathrm{C}$ temperature until slightly brownish color. The tube containing the pollen sample was left for 2-3 minutes, then centrifuged 30 rotation with 3 repetitions. The solution in the tube removed and replaced with $10 \mathrm{ml}$ of distilled water and centrifuged again 30 rotation with 3 repetitions. The washing process is carried out 3 times, and each washing is done by centrifuge. Coloring with added $1 \%$ safranin solution and $70 \%$ alcohol and glycerin jelly then stirred with a stirring rod. Pollen samples are taken with a stirring rod and placed on top of a glass object and cover with a glass cover. Pollen samples were labeled then observed under a microscope.

Identification includes documentation, observation of undergrowth morphology found with Naidu (2012) and identification of pollen, including observing morphological characters with Tschudy and Scott (1969). The pollen unit, pollen shape, and pollen aperture observed, then the pollen diameter is measured.

\section{RESULT AND DISCUSSION}

The results of the identification of the morphology of the pollen of undergrowth plants found 6 species belonging to 6 different families consist of Marantaceae, Rubiaceae, Acantaceae, Cucurbitaceae, Asteraceae, and Capparidaceae. Some of them are plants whose fruit can be consumed as vegetables, medicine and some that live as weeds. Pollen observations in 6 plant species were found to have varying pollen morphological characters (Table 1).

The first species is Maranta arundinacea L. or commonly called garut (Figure 2.I) from Marantaceae family, namely. $M$. arundinacea $L$. is a herbaceous plant that lives perennially. This plant has a round stem shape and there are rhizomes. The leaves are ovate shaped with pinnate leaf bones and have a sheath covering the stem. M. arundinacea L. has racemose flower, small in size, white flower petals and light green crown. Observation of $M$. arundinacea L. pollen showed that this species has a monad unit, a polar length of $22 \mu \mathrm{m}$, equatorial diameter of $17 \mu \mathrm{m}$, sub-spheroidal shape, tricolpate apertura and psilate ornamentation. (Figure 2.II). This is in accordance with Andersson (1998) which states that the pollen members of Marantaceae family have a spheroidal shape with psilate ornamentation. 
BioEksakta: Jurnal Ilmiah Biologi Unsoed

Volume 1, Nomor 2 (2019): 104-108

Table 1. Morphological Observation Results of Undergrowth Pollen

\begin{tabular}{cllc}
\hline No & \multicolumn{1}{c}{ Species } & $\begin{array}{c}\text { Pollen } \\
\text { unite }\end{array}$ & $\begin{array}{c}\text { Average of } \\
\text { polar length equad } \\
(\mu \mathrm{m})\end{array}$ \\
\hline 1 & Maranta arundiacea & Monad & 22,0 \\
2 & Ixora nigricans & Monad & 22,5 \\
3 & Asystasia gangetica & Monad & 70,0 \\
4 & Momordica charantia & Monad & 25,0 \\
5 & Cyathilium cinereum & Monad & 23,5 \\
6 & Cleome rutidosperma & Monad & 15,5 \\
\hline & & & \\
& & &
\end{tabular}

Figure 2. Maranta arundinacea L plant. Note : (I) Flower morphology; (II) Pollen on 400x magnification.

The second species is Ixora nigricans R.Br. ex Wight \& Arn or commonly called soka is one of the Rubiaceae family members in the form of shrubs that normally live in the forest. This plant has a simple leaf type with a pointed leaf tip (acuminate), thin leaves, no hair and has black color when dry. The stem has a length of about $0.4-1.2 \mathrm{~cm}$, white flowers arranged in terraced (cymosa) located at the top of the stem (Figure 3.I). This is in accordance with Bridson \& Robbrecht (1985) that the genus Ixora has a pollen unit monad and a tricolporate apertura which means it has 3 colpus and 3 porus. Another research conducted by Zahrina et al. (2017) shows the pollen morphology of the genus Ixora has tricolporate aperture and reticulate ornamentation. Another member of the Rubiaceae, the genus Coffea, has a spheroidal shape, most of the tetracolporate apertures and also found a tricolpate with a semi-tectate exin ornamentation and a partial reticulate (Chinnappa \& Warner, 1981). This proves that the morphological characters of the genus Ixora and Coffea have similarities in shape, while other characters have variations that can be used as identifying tool from the genus to species level.

The third species is Asystasia gangetica (L.) T. Anderson which belongs to the Acantaceae family (Figure 4.I). A. gangetica (L.) T. Anderson or locally known as ara sungsang is a herbaceous perennial plant. This plant has a height of $30-60 \mathrm{~cm}$, dark green leaves shaped rounded eggs (ovate) with the base has heart shape (cordate) and the tip of the leaf is taper (acuminate). Compound flower types are lined at the end (terminal) and white flowers with purple spots. Based on the results of pollen identification, A. gangetica (L.) T. Anderson has a monad pollen unit, $70 \mu \mathrm{m}$ polar length, $44.5 \mu \mathrm{m}$

(

Pollen shape $(\mathrm{P} / \mathrm{E})$

Aperture Ornamentation

17,5 Sub-speroidal

22,5

44,5

Sub-speroidal

Tricolpate

Psilate

21,0

Prolate

Tricolporate

Reticulate

23,5

Sub-speroidal

Tricolporate

Perforate

23,5
13,0

Sub-speroida

Tricolporate

Reticulate

Sub-speroidal Tricolporate

equatorial diameter, prolate shape, tricolporate aperture and perforate ornamentation type (Figure 4.II). This is in accordance with Lippi \& Rossi (1999) which states that the morphology of the pollen A. gangetica (L.) T. Anderson has prolate shape and tricolporate apertures with 6 pairs of pseudocolpi. Supported by the statement of AlHakimi et al. (2017) that ornamentation of $A$. gangetica (L.) T. Anderson is perforate. When compared with other members of the family Acanthaceae, the Ruellia genus, the similarity is found in the form of pollen while the apertures in the Ruellia genus are triporate with reticulate ornamentation (Tripp, 2007).
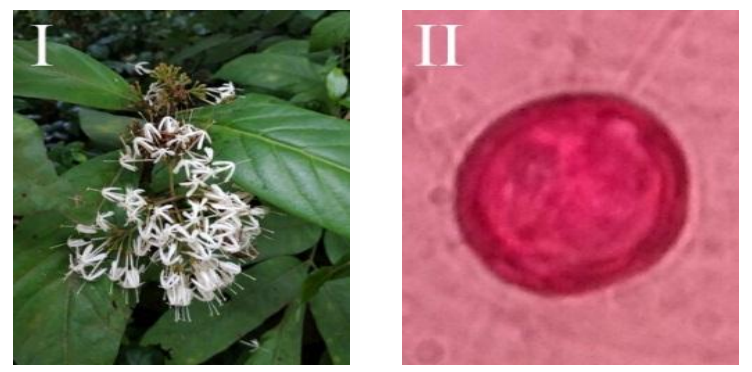

Figure 3. Ixora nigricans R.Br. ex Wight \& Arn plant. Note : (I) Flower morphology; (II) Pollen on 400x magnification.
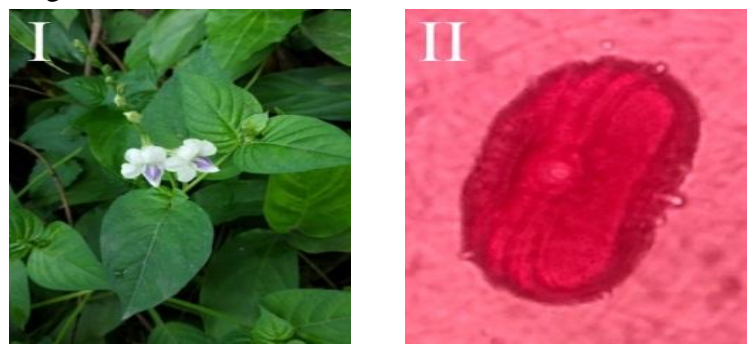

Figure 4. Asystasia gangetica (L.) T. Anderson plant. Note : (I) Flower morphology; (II) Pollen on 400x magnification.

The fourth species is Momordica charantia L. or commonly known as pare, belongs to the Cucurbitaceae family (Figure 5.I). This plant has many branches with a single leaf with a long petiole, leaf edge like a finger (palmatipartite). Single flowers are yellow with separate male and female flowers. Male flowers have yellow pistils and stamens, while female flowers have pistil and green stamens. M. charantia L. fruit is long and dark green. Based on observations, $M$. charantia L. has a monad pollen unit, $25 \mu \mathrm{m}$ polar length, $21 \mu \mathrm{m}$ 
equatorial diameter, sub-spheroidal shape, a tricolporate aperture and a reticulate ornamentation type (Figure 5.II). This is accordance with Perveen \& Qaiser (2008) that the pollen morphology of $M$. charantia L. has monad unit, sub-prolate to spheroidal oblate, tricolporate apertures with colpus extending to curvature with sharp edges and reticulate ornamentation type. Other species of the Cucurbitaceae family, namely Cucurbita balsamina L. has the shape of oblate spherical, tricolporate apertures with reticulate ornamentation (Van Rensburg et al., 1985).
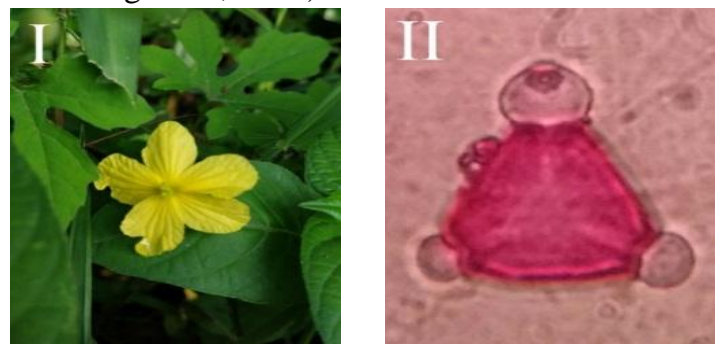

Figure 5. Momordica charantia L. plant. Note : (I) Flower morphology; (II) Pollen on 400x magnification.

The fifth species is Cyanthillium cinereum (L.) H. Rob. or sawi langit that belongs to Asteraceae family. This plant is a herbaceous annual plant with a maximum $1 \mathrm{~m}$ height, type of leaf rosette root with a round shape like egg (ovate), compound flowers with a purplish or pink crown and split 3-5 at the ends (Figure 6.I). Observation of $C$. cinereum (L.) H.Rob pollen morphology that obtained are monad unit, polar length $23.5 \mu \mathrm{m}$, equatorial diameter 23.5 $\mu \mathrm{m}$, sub-spheroidal shape, fenestrate aperture and echinate ornamentation type (Figure 6.II). This is in accordance to Salamah et al. (2019), that $C$. cinereum (L.) H.Rob. has monad unit, spheroidal shape, the type of apertura has many openings or fenestrates and the type ornamentation is echinate. One member of the Asteraceae family, Zinnia elegans L., has the same morphological character of pollen as $C$. cinereum (L.) H. Rob. except for the apertura, namely tricolporate (Salamah et al., 2018).

The sixth species is Cleome rutidosperma DC. or maman ungu that included in the family Capparidaceae (Figure 7.I). This plant is an annual herbaceous plant with a height of $15-100 \mathrm{~cm}$, threeleaf compound leaflets (trifoliate) elongated round shape with a length of about $2-5 \mathrm{~cm}$ and stiff stems with thin spines spread on the surface. The flower consists of 4 petals with red to pink or light purple and the fruit is shaped like a green capsule with a length of $5-7 \mathrm{~cm}$. Based on observations, $C$. rutidosperm DC. has a monad pollen unit, a polar length of $15.5 \mu \mathrm{m}$, an equatorial diameter of $13 \mu \mathrm{m}$, sub-spheroidal shape, tricolpate apertures with psilate ornamentation type (Figure 7.II). This is in accordance with Rahmayanti et al. (2014), which states that members of the Capparidaceae family have a form of pollen prolate to spheroidal and tricolporate apertures. Another example of a member of the Capparidaceae family is Cadaba fruticosa (L.) Druce., which has a sub-prolate pollen form with a tricolporate apertura and psilate ornamentation (Perveen \& Qaiser, 2001). Of the two species, some similarities can be seen in the type of ornamentation, while the other morphological characters have differences in shape and aperture.
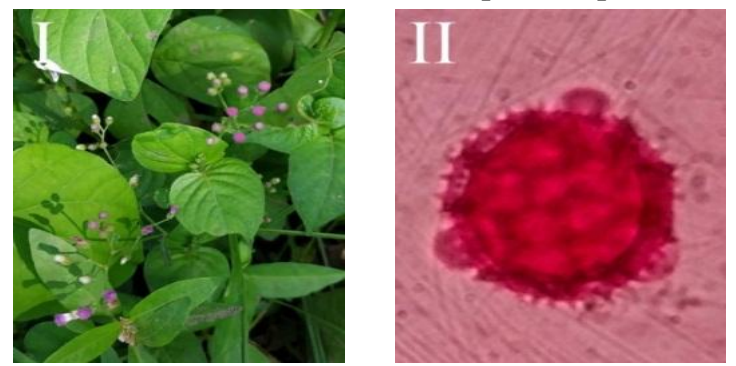

Figure 6. Cyanthillium cinereum (L.) H.Rob. plant. Note : (I) Flower morphology; (II) Pollen on 400x magnification.
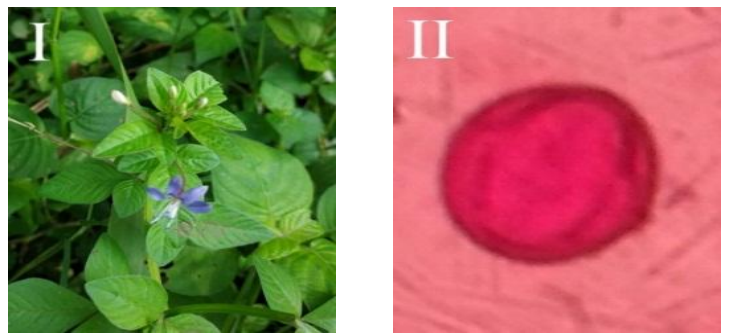

Figure 7. Cleome rutidosperma DC. plant. Note: (I) Flower morphology; (II) Pollen on 400x magnification.

The results of identification of flowering undergrowth found in the Bantarbolang Nature Reserve are members of 6 different families, namely Marantaceae, Rubiaceae, Acantaceae, Cucurbitaceae, Asteraceae and Capparidaceae. The most commonly undergrowth that found are weed plants that consist of Maranta arundinacea L., Asystasia gangetica (L.) T. Anderson, Cyanthillium cinereum (L.) H.Rob. and Cleome rutidosperma DC. There is 1 species which is an ornamental plant, Ixora nigricans $\mathrm{R}$.Br. ex Wight \& Arn and 1 plant species that can be consumed is Momordica charantia L.

Each undergrowth species found has different pollen morphological characters except for the pollen unit, monad. Pollen shape obtained from the measurement of the polar axis and diameter equatorial index found 5 species with sub-spheroidal form $(0.75-1.33 \mu \mathrm{m})$ and 1 species with prolate form $(1.33-2 \mu \mathrm{m})$. The smallest equatorial pollen diameter was found in Cleome rutidisper DC with a size of $13 \mu \mathrm{m}$ and the largest equatorial diameter of the pollen was found in Momordica charantia L with a size of $44.5 \mu \mathrm{m}$. The type of apertures found in the observations varied, namely 4 species with the tricol Corporate type, 1 species with the tricolpate type and 1 species with the fenestrate type. Ornamentation also observed varied, namely 2 species having psilate type, 2 reticulate species, 1 perfolate species and 1 echinate species. 


\section{CONCLUSION}

The morphological character of pollen of undergrowth plant found in Bantarbolang Nature Reserve has variations in the shape of pollen (subsperoidal and prolate), apertures (tricolpate, tricolporate and fenestrate) and ornamentation types (psilate, reticulate, perforate and echinate). While the pollen units of all species have monad type.

\section{REFERENCES}

Al-Hakimi, A.S., Maideen, H., Saeed, A.A., Faridah, Q.Z. \& Latiff, A., 2017. Pollen and seed morphology of Justicieae (Ruellioideae, Acanthaceae) of Yemen. Flora, 233, pp. 3150 .

Allard, R.W. 1992., Pemuliaan Tanaman I. Jakarta: Rineka Cipta.

Andersson, L., 1998. Marantaceae. In Flowering Plants. Monocotyledons. Springer, 4, pp. 278-293.

Aththorick, T. A., 2005. Kemiripan Komunitas Tumbuhan Bawah pada Bberapa Tipe Ekosistem Perkembunan di Kabupaten Labuhan Batu. Jurnal Komunikasi Penelitian, 17(5), pp. 42-49.

BKSDA Jateng., 2018. Cagar Alam Bantarbolang. [online] Available at: <http://bksdajateng.id/home/kawasan_blog.p hp?id=GEy20NfSCUI=> [Diakses pada 29 Desember 2018].

Bridson, D. M., \& Robbrecht, E., 1985. Further Notes on the Tribe Pavetteae (Rubiaceae). Bulletin $d u$ Jardin botanique national de Belgique, 6(55), pp. 83-115.

Chinnappa, C. C. \& Warner, B. G.,1981. Pollen morphology in the genus Coffea (Rubiaceae) and its taxonomic significance. Botanical Journal of the Linnean Society, 83(3), pp. 221-236.

Kumaladita, L., 2014. Hubungan Kekerabatan JenisJenis Tumbuhan Anggota Sub Famili Caesalpinioideae di Daerah Istimewa Yogyakarta Berdasarkan Kajian Morfologi Serbuk Sari Sebagai Sumber Belajar Biologi Siswa SMA Kelas X. Jupermasi, 1(1), pp. 93-97.

Kunarso, A. \& Azwar, F., 2013. Keragaman Jenis Tumbuhan Bawah pada Berbagai Tegakan Hutan Tanaman di Benakat, Sumatera Selatan. Jurnal Penelitian Hutan Tanaman, 10 (2), pp. 85-98.

Kurnia, A. \& Arief, D. S., 2015. Kalibrasi Mikrometer Sekrup Eksternal dengan Mengacu pada Standar Jis B 7502-1994 Di Laboratorium Pengukuran Teknik Mesin Universitas Riau. Jom FTeknik, 2(2), pp. 19.

Lippi, M.M. \& Rossi, W., 1999. Pollen morphology of some Acanthaceae from West Africa. Plant Biosystem, 133(1), pp.73-82.
Maisyaroh, W., 2010. Struktur Komunitas Tumbuhan Penutup Tanah di Taman Hutan Raya R. Soerjo Cangar, Malang. Jurnal Pembangunan dan Alam Lestari, 1(1), pp. 19.

Mikaf, F., 2013. Studi Morfologi Serbuk Sari pada beberapa Varietas Coleus scutellarioides L. Eksakta, 2, pp. 99-106.

Naidu, V.S.G.R. 2012. Hand Book on Weed Identification. Jabalpur: Directorate of Weed Science Research.

Perveen, A. \& Qaiser, M., 2008. Pollen flora of Pakistan-LVI. Cucurbitaceae. Pakistan Journal of Botany, 40(1), pp. 9-16.

Perveen, A., \& Qaiser M., 2001. Pollen flora of Pakistan-xxxi Capparidaceae. Turkish Journal of Botany, 25(6), pp. 389-395.

Ratnasari, J., 2007. Galeri Tanaman Hias Bunga. Bogor: Penebar Swadaya.

Salamah, A., Luthfikasari, R. \& Dwiranti, A., 2019. Pollen morphology of eight tribes of Asteraceae from Universitas Indonesia Campus, Depok, Indonesia. Biodiversitas Journal of Biological Diversity, 20(1), pp.152-159.

Salamah, A., Luthfikasari, R., \& Dwiranti, A., 2019. Pollen morphology of eight tribes of Asteraceae from Universitas Indonesia Campus, Depok, Indonesia. Biodiversitas Journal of Biological Diversity, 20(1), pp. 152-159.

Suharti, S., 2015. Pemanfaatan Tumbuhan Bawah di Zona Pemanfaatan Taman Nasional Gunung Merapi oleh masyarakat sekitar hutan. Prosiding Seminar Nasional Masyarakat Biodiversitas Indonesia, 1(6), pp. 1411-1415.

Tripp, E. A., 2007. Evolutionary relationships within the species-rich genus Ruellia (Acanthaceae). Systematic Botany, 32(3), pp. 628-649.

Tschudy, R. H, \& Scott, R.A. 1969. Aspect of Palynology.New York: John Willey and Sons.

Van Rensburg, H. J., Robbertse, P. J., \& Small, J. G. C., 1985. Morphology of the anther, microsporogenesis and pollen structure of Momordica balsamina. South African Journal of Botany, 51(2), pp. 125-132.

Widhiono, I. \& Sudiana, E., 2015. Peran Tumbuhan Liar dalam Konservasi Keragaman Serangga Penyerbuk Ordo Hymenoptera. Prosiding Seminar Nasional Masyarakat Biodiversitas Indonesia, 1(7), pp.1586-1590.

Zahrina., Hasanuddin \& Wardiah., 2017. Studi Morfologi Serbuk Sari Enam Anggota Famili Rubiaceae. Jurnal Ilmiah Mahasiswa Fakultas Keguruan dan Ilmu Pendidikan Unsyiah, 2(1), pp. 114-12. 